\title{
APOTROPAIC SYMBOLISM AT POMPEII: A READING OF THE GRAFFITI EVIDENCE.
}

\author{
Pedro Paulo de Abreu Funari \\ History Department - Unicamp
}

\begin{abstract}
RESUMO: O artigo trata de algumas inscriçōes romanas cursivas antigas, de Pompéia, enquanto evidência de hábitos apotropaicos. Grafites fálicos e sexuais explícitos são estudados como representativos do uso popular de expressōes obscenas para afastar as forças maléficas.

ABSTRACT: The paper deals with some Old Roman Cursive inscriptions from Pompeii as evidence of apotropaic habits. Explicit phallic and sexual intercourse graffiti are studied as representative of ordinary people's use of obscene expressions for warding off evil influences.
\end{abstract}

PALAVRAS-CHAVE: Sociedade romana, grafites, Pompéia, simbolismo apotropaico, religiāo romana.

KEY-WORDS: Roman society, graffiti, Pompeii, apotropaic symbolism, Roman religion.

\section{Introduction}

Apotropaic acts and symbolism for warding off the evil eye or the evil influences played an important part in the Roman Society. Phallic representations and illustrations were particularly used to turn away (cf. the Greek root of apotrépein, "to turn away") evil forces: contra inuidentium effascinationes, against cnvious charms (GR baskaino) (Pliny, N.H.19,50). It is usually accepted that the apotropaic function of the phallus is linked to its association with fertility (e.g. ADAMS, 1987, pp. 4-6, with earlier bibliography on the subject). Different terms which referred to the phallus are thus considered apotropaic, namely mentula, verpa, fascinum, phallus and perhaps even cauda. Different classical authors attest to the apotropaic character of male genitalia. Costas Panayotakis emphasizes, for instance, that some of Petronius' passages (e.g. Sat. 22, 1; 134, 11; 138, 1) suggest a sexually symbolic rather than pornographic interpretation (personnal communication). Related expressions, especially those referring to the scxual intercourse with a woman, are however and unexpectedly usually not associated to apotropaic connotations. Adams (1987, p. 120) was thus able to state that "it seems that futuo [to fuck] was freely 
used as an unemotive technical term in brothels by both clients and prostitutes".

Not long ago, the Portuguese anthropologist João de Pina-Cabral (1993, pp.117-118), struck by the ubiquity of phallic displays at ordinary people's level, decided to study the genital symbolism in Portuguese popular culture. Pina-Cabral (1993, pp.117-118) concluded that the purpose of phallic manipulation "is to capture power and use it". From my own expcrience with Roman cursive inscriptions, 1 was impressed by the references to the phallus and by the constant use of expressions referring to the malc intercourse with women. Reading the thousands of ordinary people's grafitti found at Pompeii and published in the fourth volume of the Corpus Inscriptionum Latinarum (hereafter CIL IV), it became obvious that there was a straighforward link between phallic representations and malc sexual intercourse references, both related to fertility and good luck.

This paper deals with some old Roman cursive inscriptions from Pompeii, for these wall scratches or scribbles are probably the best access we have to ordinary people in Roman times. These tituli graphio exarati enable the modern scholar to act like an ethnologist or oral historian in search of people's evidences. It is difficult to assess how representative of ordinary ethos any written text can be judged considering that literacy was not universal (HARRIS, 1989). However, most contemporary palacographists who deal with cursive writings emphasize the humble background of ordinary writers (e.g. JORDAN, 1990, p. 438). "A very wide spread of literate skills in the ancient world" was acknowledged by Bowman (1991, p. 123). "The vivacity and sheer mass of the evidence suggests a widely literate population", after Franklin (1991, p. 81; cf. BEARD, 1991, p. 37). "Lots of people could write, and there was quitc a lot to read", in Hopkins' (1991, p. 152) words. Lower social and economic strata are also widely attested in cursive tablets (TOMLIN, 1988, p. 80). Giovanni Menella (1992, p. 7), studying countryside epigraphy in northern Italy, was struck by the fact that "poorly literate individuals were able to write short texts on unfinished materials thanks to the use of portable and unexpensive stylets". Even frontier peoples are said to be literate: "we note the rather high state of literacy among those Roman-times Beduins" (GICHON, 1983, p. 585). The acceptance of the fact that there was widespread literacy (alphabétisation largement répandue in CORBIER's words 1991, p: 118 ) is, of course, the result of an inevitable bias: specialists on cursive inscriptions are naturaly prone to consider that the hard times dedicated to the deciphering of obscure inscriptions do represent a contribution to the knowledge of a large number of people (GORDON, BEAR, REYNOLDS \& ROVECHÉ, 1993, p. 154). The use in these writings of Vulgar Latin, however, strengthen considerably the argument.

Pompcian graffiti are still underestimated as a source of Roman customs and Weltanschauung. Amy Richlin's The Garden of Priapus and Catherine Johns' Sex or Symbol? deal with the phalfus and its apotropaic connotations but both authors are not particularly concerned with scribbles. Richlin (1983) and Johns (1982), among others, greatly contributed to our understanding of phallic symbology in general and particularly as represented in elite evidences, literary texts, scholarly paintings and so on. Although ordinary people's scribbles should not be opposed to elite expressions as they refer to one and the same society and culture, it is, however, rcasonable to emphasize the specificity of popular culture. Carlo Ginsburg (1986, p. 95) stressed that as an analytical model it is "more useful a bipartition between popular and learned culture than a holistic one”. The anthropologist Joāo de Pina-Cabral (1993) attests to the importance of the distinction between popular and learned cultures: Pina-Cabral studied 
popular genital symbolism which was completely foreign to his learned culture. This is the main aim of this paper: to look for the apotropaic implications of ordinary scribbles.

\section{Apotropaic wall scribbles at Pompeii}

Pompeii was not an ordinary Roman townlet, Pompeji eine weltoffene Stadt war mit einer bemerkenswerten Aktivitaet seiner Einwohner, cosmopolitan in outlook (SOLIN, 1973, p. 98), its graffiti representing the feelings of a wide variety of people. Phallic drawings on the city walls are not uncommon. Sometimes ithyphallic drawings are particularly interesting as the erectum fascinum is larger than the man himself. On the walls near the Theater quarter there is a drawing of an ithyphallic gladiator using his penis as a weapon (VIVOLO, 1993, pp.148-149; Figure 1). Taking into account the strongly religious connotations associated to gladiatorial fights (HUGONIOT, 1992, p. 12), it seems likely that the phallic representation of the gladiator was intended to protect him against the evil (cf. Porph. Ad. Epod. 8, 18: fascinum pro uirili parte posuit quoniam praefascinandis rebus haec membri deformitas apponi solet; cf. TUPET, 1986, pp. 2609-2675).

Another ithyphallic drawing (CIL IV, 4566; Figure 2) is followed by an unclear inscription: Felicio tomintare. Although still unexplained, this graffito must be related to tumeo (to swell) or to torqueo (to twist), whilst felicio is related to felix, fertile and lucky (cf. VAANANEN, 1937, pp. 43-49). It could thus be interpreted as a reference to the phallus being waved or swollen. Good luck and fertility can also be associated to the drawing of a man whose head is completed by a phallus (VIVOLO, 1993, p.179; Figure 3). Phallic drawings could explicitly act as a protection against the evil eye or female contempt. Male dominated societies, phallocentric in character (GOLD, 1993, p.79), do tend to generate in men a fear of female sexual assessments. Women were not powerless, as they could choose their mates (cf. GILMORE, 1990) and a graffito by. a man named Fortunatus is a case in point (CIL IV, 4498; Figure 4): Thyas noli amare Fortunatum uale, "Thyas does not want to love Fortunatus. Farewell". Before the greetings, the phallic drawings acts as a good luck safeguard.

Phallic drawings were also used to substitute phallum in a phrase, like CIL IV, 4756 (Figure 5): q() habiat Clymene phallum, "Clymene, hold the phallus" (cf. VAANANEN, 1937, p. 62). The first letter, apparently a $q$, remains unexplained if we accept Mau's interpretation in the Corpus Inscriptionum Latinarum. Zangemieister, quoted by Mau, proposed to read it Quintus habeat Clymenen, "Quintus shall have intercourse with Clymene". Perhaps we should suggest that the penis is the agent or subject of the phrase: describo phallum quod habiat Clymenen, "I draw this phallus which will have intercourse with Clymene" (cf. VAANANEN, 1963, pp. 173-175). The association of the phallic drawing to the written message was probably carried out to lure the good luck. The strength associated to the penis is also clear in other graffiti, like CIL IV, 1655 (Figure 6): Hysocryse puer Natalis uerpa te salutat, "Young Hysocrysus, Natalis the phallus greets you".

Male genitals, as a symbol of creative nature, were respected with religious piety as the representation of the misterious forces of creation, and at the same time they were used as apotropaic amulets against all human and divine evil (MONTERO, 1991, p. 69).

Pompeian graffiti referring explicitly to the male sexual intercourse with women are also very common. Eva Cantarella (1988, p. 276) emphasized that "the sexual mentality of Roman males was that of a raper, a consummate raper". The most popular word used on the walls was the verb futuo ("fuck") and 
12

Pedro Paulo A. Funari / Revista de História 132 (1995), 9.17
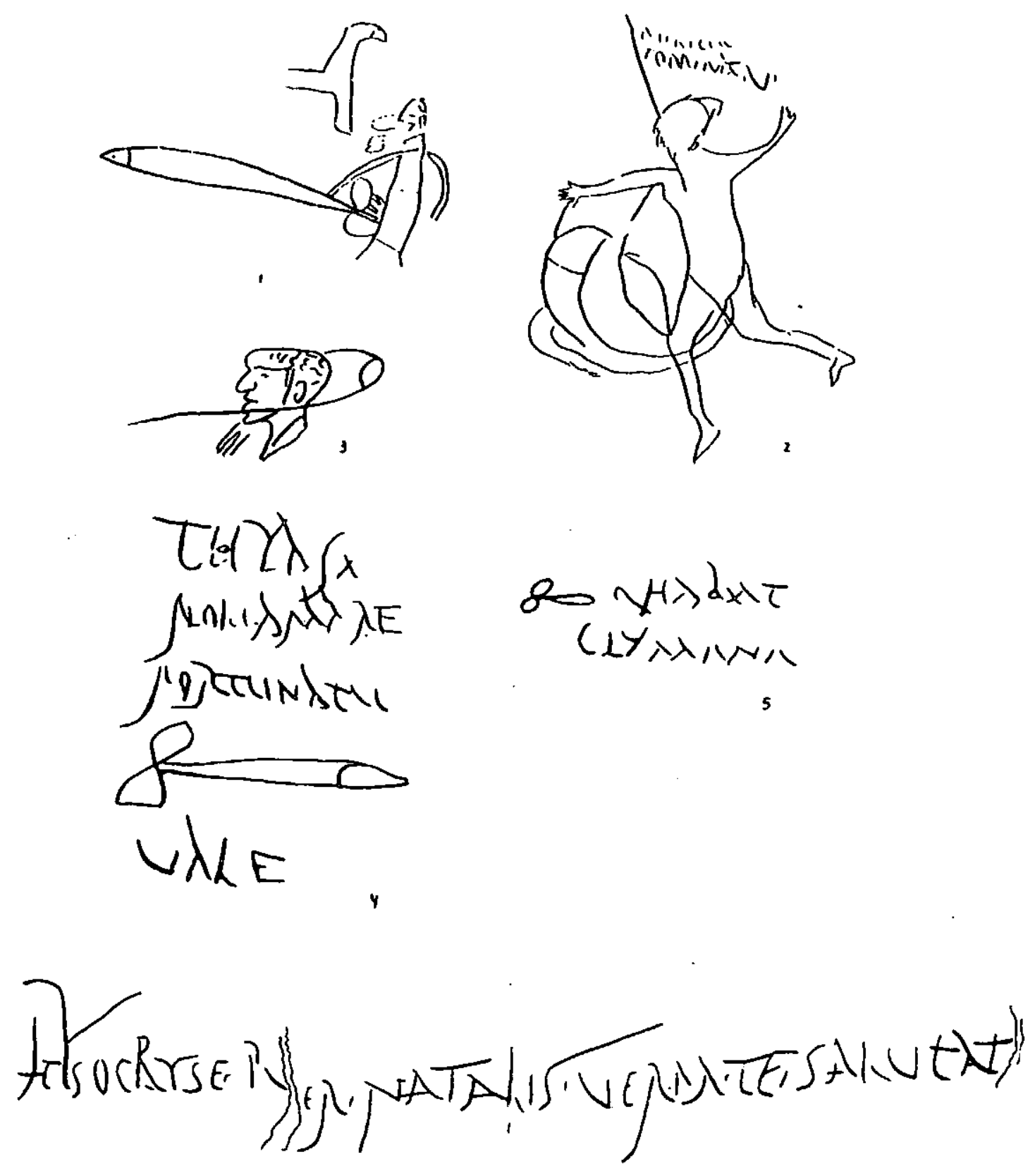

Figures 1-2-3-4-5-6 
related terms (originally "hit, bit"?; cf. ADAMS, 1987, p. 118). Like its Greek counterpart bineo, also used at Pompeii (e.g. CIL IV, 8767), ancient authors associate it to the use of force (cf. LAMBERTERIE, 1991, pp.149-156). However, as John Boardman (1992, pp. 239-240) has stresscd recently, phallic references and intercourse with women do not necessarily mean aggression by men against women and, indeed, most graffiti referring to fututiones are not offensive. Furthermore, they secm do have the same apotropaic connotations of their phallic counterparts.

In one of the brothels of Pompeii, many graffiti refer to the sexual intercourse. Most of them are clearly harmless, like CIL JV, 2246 (Figure 7): hic ego cum veni, futui, deinde redei domi, "I came here, I have fucked and finally I came back home". Similarly, "Placidus fucked here whomsoever he wanted", Placidus hic futuit quem uoluit (CIL IV, 2265; Figure 8). Some phrases are complex: "the vagina of Roman citizens was fucked, their legs open; there are no substitutes, except for the most swect and kind", futebatur, inquam futuebatur, ciuium Romanorum atractis pedibus cunus in qua nule aliae uices erant nisissei dulcisime et pissimae (CIL IV, 1261). Even though difficult to interpret since the text was written as a transcription of oral language, it is interesting to note the use of a term with strong religious connotations, piissimae sc. mulieres - "the most blessed women" - in connection with a fututio (for a different interpretation, see ADAMS, 1987, p. 121).

Some phrases are clearly propitiatory. "You are in good shape if you are a good fucker", bene valeas qui bene futues (CIL IV, 2274; on the language, see VAANANEN, 1937, p. 36). The same interpretation applies to an inscription in Brothel Street (Vico del Lupanare) by a woman: "I was fucked here", fututa sum hic (CIL IV, 2217; Figure 9). Adams (1987, p. 120) commented on this graffito remarking that "it is not the sort of remark one would expect from a person who considered that she had been the victim of a hu. miliating act". He is obsviously right, but this does not mean that it was a "neutral use of the word". If the fututio was considered as a lucky act, naturally both males and females would use the word to protect themselves against the evil. This hypothesis is strenghtened by graffiti referring to women as "female fuckers". Two inscriptions refer to "Mula the fucker", Mola phoutoutris (in Greek, CIL IV, 2204; Figure 10; cf. DUBUISSON, 1992, p. 189) and "Miduse the fucker", Miduse fututrix (CIL IV, 41.96; Figure 11). It secms that the only reasonable explanation for these inscriptions is that the fututio was praiseworthy for men and women alike.

A poorly spelled graffito is probably an interesting evidence of the popular use of references to sexual intercourse as a lucky device. "Lustful lad, how many women have you fucked!", filius salax qud tu mulieriorum difutuisti (CIL IV, 5213; Figure 12). A number of vulgarisms in the phrase make its interpretation difficult, but it does not seem likely that filius salax (literally, "youngster fond of leaping") was pejorative (contra ADAMS, 1987, p. 206). The use of salax to refer to a boy, considering that the word was used mostly in relation to male animais, can be explained by the fact that the writer was a very humble person, probably acquainted with countryside slang. This could also explain the use of filius ("son") as "lad" (VAANANEN, 1937, p. 191). Furthermore, there are other references to good or bad luck and as a result of fututiones. The well-known Floronius inscription is a case in point: "Floronius, fucker and soldier of the seventh legion, was here <sc. an inn> and no woman realized the fact...but they were only six and so they would be too small a number <sc. for this boastful male" >, Floronius binet ac miles leg. vii hic fuit, neque mulieres scierunt, nisi paucae, et ses, erunt (CIL IV, 8767; Figure 13; cf. FUNARI, 1993, p. 134). The intention of Floronius with this graffito was to protect himself from the bad luck which could result from his abstinence. To avoid it, he refered to himself as a f ucker, 
14

Pedro Paulo A. Funari / Revista de História 132 (1995), 9-17

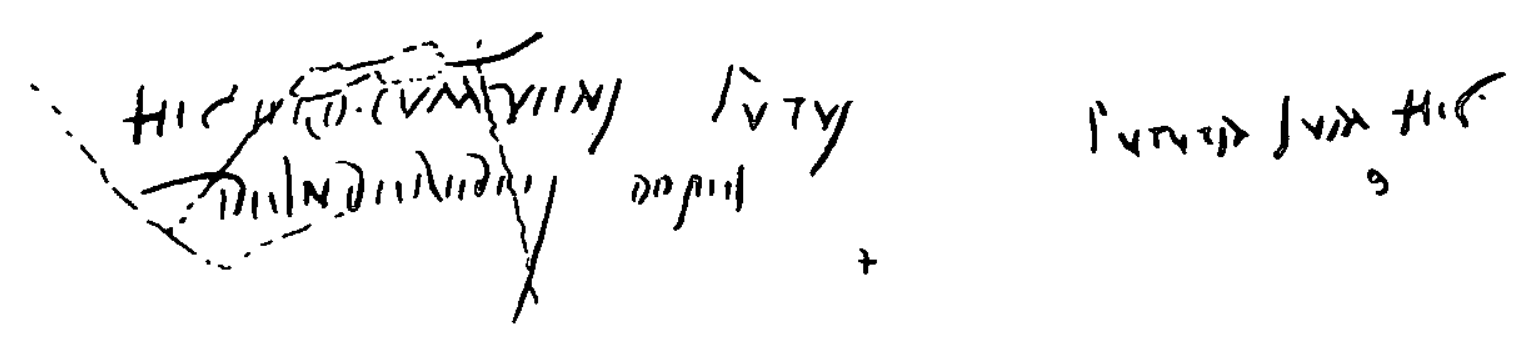

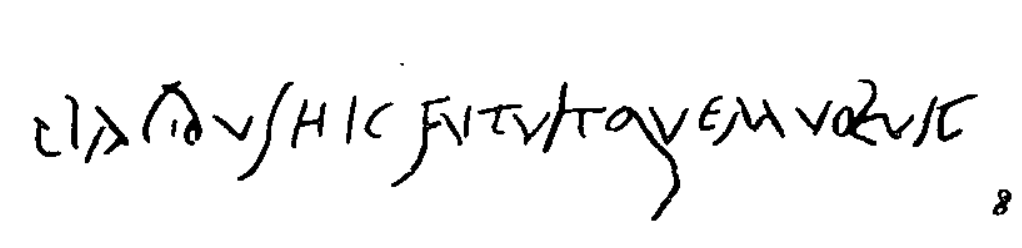

MPM)MUTாRIx

MU'A. QOYTOF⿻二丨

juLAS SALAX

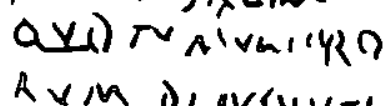

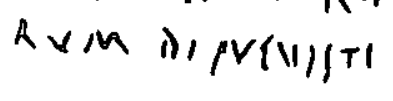

12

FLOR QNIN/. b. NETDCWLIEI LEG-पा1HIL.

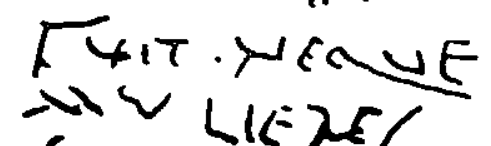
SCIERVNUTES

CAU GSE.ET

IESER NTT. IS
MHCHABUIINT

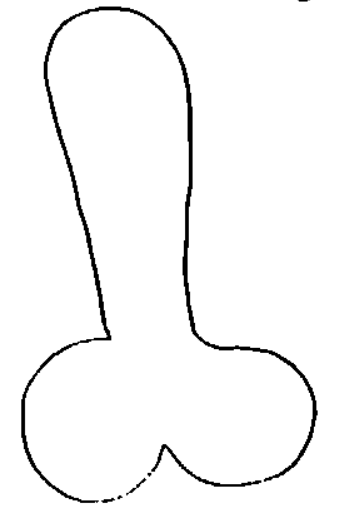

FTURUAS

Figures 7-8-9-10-11-12-13-14 
binetas in Greek, and thus reasserted his sexual capacity.

\section{Conclusion}

Is it possible to conclude from these examples that explicit references to sexual intercourse were apotropaic? There is no easy answer to this question. It is widely recongnized that the phallos was charged with deep religious feelings, acting as an actual apotropaic symbol. On the other hand, the widespread usc of references to the sexual intercourse by ordinary people is usually not explained. This practice could not be cxplained satisfactorily by natural sexual desire alone (cf. BING \& COHEN, 1991, p. 1). It is, on the other hand, easy to understand that if fertility was at the root of the magic properties attached to phallic representations, it should also explain the popularity of references to sexual intercourse. Long ago Pierre Grimal (1969, pp. 47-49) keenly stressed that fertility cults were common not in the elite people but among "freedmen, slaves, very ordinary people" (le menu peuple). The concern with bad luck and evil eye was also characteristic of humble people (JORDAN, 1990, p. 438). Within the popular religious culture, la culture religieuse populaire (KUENZEL, 1992, p. 1055), there is no reason to supposc that fututiones were not associated to the phallus and that sexual intercourse as well as phallic references were both linked to fertility and good luck. The "religion of uncultivated people", religion des gens incultes (GOUREVITCH, 1991, p. 136), although difficult to grasp, is surely to be found in Old Roman Cursive Inscriptions written in Vulgar Latin (die Sprache der niederen Klassen, VOSSLER, 1954, p. 49).

The ubiquity of references to the sexual intercourse in wall scribbles is striking and the terms used to refer to it comprise related subjects as well, like fructus "enjoyment" (e.g. CIL IV, 2245) and felicitas "happiness, luck" (JOHNS, 1982, p. 65; CIL IV, 1454; Figure 14). Gestures are a clear indication of the association of sexual intercourse and the warding off of evil influences, as the use of the fingers to mimic sexual intercourse indicates (cf. Ov. Fast. 5, 433). Ritual obscenity, obscene wedding songs and other fertility and apotropaic ceremonial acts should thus not be isolated from ordinary sexual references. It secms reasonable to suppose that the daily use of sexual language, as represented in the graffiti, was the result of the apotropaic properties associated to the sexual intercourse itself and to the oral and written reference to it. For defenseless ordinary pcople, subject to the manifestation of the evil as illnesses, poverty and hunger, the spelling and writing of sexual words could at least be an affordable way of warding off bad luck. The anonymous scribbler had no doubt about that: "here dwells good luck" (Figure 14).

\section{Acknowledgements}

The draft version of this paper was read at the Museu de Arqueologia e Etnologia da Universidade de Säo Paulo, on the first of July, 1994, as well as at the Symposium on the Archaeological Source Material and the Reconstruction of History, World Archaeological Congress 3, in December 1994, New Delhi, India. I owe thanks to the following friends and colleagues who forwarded papers, exchanged ideas, or read the draft version and helped me in different ways: Scott Allen, Mordehai Gihon, Norberto Luiz Guarinello, Costas Panayotakis, José Remesal and Heikki Solin. The ideas presented here are my own for which I alone am therefore responsible. 
Bibliography

ADAMS, John N. The Latin Scxual Vocabulary. London , Duckivorlh, 1987.

BEARD, Mary. "Writing and Religion: Ancient Literacy and the Function of the Written Word in Roman Religion. Question: What Was the Role of Writing in GraccoRoman Paganism?" In: HUMPHREYS, John H. (ed.). Litcracy in the Roman World, Ann Arbor: Journal of Roman Archacology Supplementary serics $n^{\prime \prime} 3,1991$, pp. 35-58.

BING, Peter \& COHEN, Rip. Games of Venus. An Anthology of Greck and Roman Erotic Verse From Sappho to Ovid. London, Routledge, 1991.

BOARDMAN, John. "The Phallos-bird in Archaic and Classical Greek Arı". Revuc Archcologiquc, 2, 1992, pp. 227-242.

BOWMAN, Alan.K. "Lilerncy in the Roman Empire: Mass and Mode", In: HUMPHREYS, John H. (ed.). Litcracy in the Roman World, Ann Arbor: Journat of Roman Archacology supplementary series $n^{23}, 1991$, pp. 119-131.

CANTARELlA, Eva. Sccondo Natura. La Biscssualità nal Mondo Antico. Roma, Riuniti, 1988.

CORBIER, Mircille. "L'écriture en Quête de Lecteurs". In: HUMPHREYS, John. H. (ed.). Literacy and the Roman World, Ann Arbor: Journal of Roman Archacology supplcmentary serics 10.3, 1991, pp. 99-118.

DUBUisSON, Michel. "Le Grec à Rome à l'époque de Cicéron. Extension et Qualité du Bilinguisme". In: Annalcs ESC, 1, 1992, pp. 187-206.

FRANKLIN, James L. "Literncy and the Parietal inscriptions of Pompcii". In: HUMPHREYS, John H. (ed.). Litcracy in the Roman World, Ann Arbor: Journal of Roman Archacology supplementary serics $n^{2} .3,1991$, p. 77.98.

FUNARI, Pedro Paulo A. "Graphic Caricature and the Ethos of Ordinary People at Pompeii". Journal of European Archacology, 2, 1993, pp. 131-148.

GILMORE, David D. "Men and women in Southern Spain: 'domestic power' revisited". American Anthropology, 92, 4, 1990, pp. 953+970.

GICHON, Mordehai. "Who were the Enemies of Rome on the Limes Palestinne". Studien zu den Militacrgranzen Roms $/ 1 /$, Aalen, 13, Internationaler Limeskongress, 1983, pp. 584-592.
GINSBURG, Carlo. "An Interview to Keith Lurin and Romulo Gandolfo". Radical History Revicw, 35, 1986, pp. 89-111.

GOLD, Barbarn K. "But Arindne was Never There in the Fist Place: Finding the Female in Roman Poetry". In: RABINOWITZ, Nancy Sorkin \& RICHLIN, Amy (eds.). Feminist Theory and the Classics. London, Roulledge, 1993, pp. 75-101.

GORDON, Roger; BEARD, Mary; REYNOLDS, John \& ROVECHÉ, Claude. "Roman Inscriplions 1986-1990". Journal of Roman Studics, 83, 1993, pp. 131-158.

GOUREVITCH, Aron. La Science Historique el l'Anthropologie. Ciences Sociales, Moscow, 3, 1991. pp. 113-138.

GRIMAL, Picrre. Les Jardins Romains. Paris, Presses Universilaites de France, 1969.

HOPKINS, Keith. "Conquest by Book". In: HUMPHREYS, John.H. (ed.). Literacy in the Roman World, Ann Arbor: Journal of Roman Archacology supplementary serics $n^{0} 3,1991, \mathrm{pp}$. 133-158.

HUGONIOT, Claude. "Saint Augustin ct les Spectacles de l'Amphithéatre en Afrique Romaine". Histoirc de l'Art, 17/8, 1992, pp. 11-21.

JOHNS, Cntherine. Sex or Symbol, Erotic Images of Greece and Romc. London, British Museum Publicalions, 1982.

JORDAN, Dan R. "Curses from the Waters of Sulis". Journal of Roman Archacology, 3, 1992, pp. 437-441.

KUENZEL, Robert. "Paganisme, Syncrétisme et Culture Religieuse Populaire au Haut Moyen Agc, Reflexions de Méthode". Annalcs ESC, 4-5, 1992, pp. 1055-1069.

LAMBERTER!E, Chasles de. "Le Verbe Binein et le Nom de in Femme". Revuc de Philologic, 65,1, 1991, pp. 149-160.

MENELLA, Giovanni. Romanizzazione ed Epigrafia in Liguria. Originalità, Trasformazioni c Adattamcnti. Coloquio Roma y las primeras culturas epigráficas del Occidente. Zaragoza, 4-6 November, 1992, unpublished typescript.

MONTERO, Enrique. El Latin Erótico. Aspectos Léxicos y Litcrários (hasta el siglo I d.C.). Seville, Unjversidad de Sevilla, 1991.

PINA-CABRAL, Joño de. "Tamed Violence: Genilal Symbolism in Portuguese Popular Culture". Man, New Scrics, 28, 1, 1993, pp. 101-120. 
RICHLIN, Amy. The Garden of Priapus. Scxuality and Aggression in the Roman Humor. New Haven, Yale University Press, 1983.

SOLIN, Heikki. "Dic herkulanensischen Wandinschriften, ein Soziologischer Versuch". Cronache Ercolanesi, 3, 1.972, pp. 97-104.

TOMLIN, Roger S.O. "The Curse Tablets". In: CUNLIFFE, B. (ed.): The Temple of Sulis Minerva at Bath, vol. 2, The finds from the Sacred Spring. Oxford, Oxford University Committe for Archaeology, 1.988, pp. 59.278 .
TUPET, Anne Marie. "Rites Magiques dans l'Antiquité Romaine". Aufstige und Niedergand des rocmischen " Reiches, 16, 3, 1986, pp. 2591-2675.

VAANANEN, Veikka Lc Latin des Inscriptions Pompeicnnes. Helsinki, 1937.

VAANANEN, Veikko. Introduction au Latin Vulgaire. Paris, Klincksieck, 1963.

VIVOLO, F.P.M. Pompei, i Graffiti Figurati. Naples, Bastogi, 1993.

VOSSLER, Karl. Einfuchrung ins Vulgaerlatcin. Munich, Huesber, 1954.

Endereço do Autor: Departamento de História - Instituto de Filosofia e Ciências Humanas - Universidade Estadual de Campinas - Cajxa Postal 1170 - CEP 13084-100 - Campinas - São Paulo - Brasil - Fax: (0192) 39-3327. 